National Association of Language Laboratory Directors N E W S I E T T E R

Volume I, Number 2

September, 1966

President

Mr. T. R. Goldsworthy, Dir.

Language Laboratories

7103 Social Science Bldg.

The University of Wisconsin

Madison, Wisconsin 53706

Vice President

Prof. Louis J.. Chatagnier, Dir.

Language Laboratory

Emory University

Atlanta, Georgia 30333

Secretary-Treasurer

Sister M. Timona, SSND, Dir.

Language Laboratory

Mount Mary College

Milwaukee, Wisconsin 53222
This second issue of our NALLD NELSLETTER has been delayed several times, and during the interim letters have come to my desk asking what progress we have been making. This issue will try to answer those inquiries.

1. The first Newsletter was reurinted several times and sent to every college and University in the U.S.A. and some in Mexico and Canada. Many copies have been sent. to States where they were distributed to all the high school Foreign ianguage teachers in the state, with the help of State Supervisors.

2. The college and university buzk mailing required us to make up label stencils including corre ct tip codes. These labels can be addressed to either the chairman of the department or to the language laboratory director.

It occurred to us that you might have a project that vould need similar labels. If your school would be interested. In purchasing a set of labels, write us: for further particulars.

3. Uniform subscription expiration date. While we have been busy organizing NALID activities and services there has been little apparent direct help or services to NEVISLETTER subscribers. He have therefore decided to extend your subscriptians (no matter when you started) through october, I $I_{0}$. If you" have already sent in a renewal, it will be applied to next year's dues.

4. Our growing membership roster has been converted to metal adiresscgraph plates which include the correct ZIP code, as will be required for all 3 rd class bulk mailings as of 1 January, 1967. At the same time the plate is made up, membership cards are stamped fiom it for arrangement by name of person, name of institution, and by state zip code. Your address for this. newsletter was stamped from this plate. Please check it carefully to see that it is correct, and notify us if any changes need to be made. The SecretaryTreasurer will soon issue membership dues receipt cards.

5. Many high-schools, colleges and universities responded to our idea of setting up a NALLD "Publishing Center." One of the first and most generous offers of assistance came from the administration at Ohio University, located at Athens, Ohio 45701. The lab director there, Mr. Charles Richardson will direct its operation for NALID.

6. The editor of your newsletter, like all the professional colleagues who have worked so hard to make NALID grow, contributes his time and effort as his particular position at the University permits - and with the support of his University. I think it only fair to explain then what has kept me so busy that the newsletter has had to be delayed. I have been writing the specifications for six remote record language laboratories to be installed in our new nineteen story Van Hise Language Building which is nearing completion on our main campus. These specifications are in excess of seventy-five pages, and cover a dial-access automatic tape library. They are in the final stages of completion, and so our next issues will appear more frequently. 
Persons having news items, material, etc. to contribute to the newsletter should send them to the editor, Mr. T. R. Goldsworthy.

\section{NATID ACTIVITIES}

1. NAILD held its second annual official business meeting in San Diego, California confurrent with the DAVI convention on 26 ipril, 1966. Prof. Albin Iiauginas of Loyola University gave a talk on the construction of taped exercises. Then the main,speaker, Dr. J. Michael Moore of the San Diego City, School System, gave a talk on the need for language laboratory directors at the secondary level, and an interesting report on how the long Beach City Schools have used full time technicians in their labs to help the teachers utilize the equipment. A detailed summary of this talk appears on page 452 of the June-July, 1966 issue of DAVI's journal, AUDICVISUAL INSTRUCTION (1966 Convention Issue). We are investigating the possibility of making copies of this speech available through our NALID Publishing Center, because it provides job descriptions for the technician which might be interesting to high school administrators.

2. During the meeting's business session, a resolution was passed urging all publishers who produce tapes to accompany their/textbooks, to provide a complete correlated tape script and guide for the set of tapes. This would allow the tapes to be an integrated part of the course. Such guides would contain the complete script of the tape, correlations between tape reels and text chapters/pages, and accurate timing of the drills.

3.- The next Regional meeting NALID will hold is concurrent with the Modern Language Association's annual meeting in New York, New York. This regional meeting will be held on Tuesday, 27 December from 3:00 to 4:15 PM in Parlor $C$ of the Sheraton Atlantic Hotel. Space is being provided by the NiA. The MLA's convention manager, Annabel Quick, has also provided an information table at the Statler hilton where sample copies of the Newsletter will be available.

4. WLID's third annual official business meeting will be held concurrent with the DAVI annual convention-in Atlantic City, New Jersey in the Spring, during the week of $2-7$ April, 1967. At that time Prof. Louis J. Chatagnier will move from Vice President to President, while a new Vice President and SecretaryTreasurer will be installed. The nomination committee will present a slate of candidates via the newsletter, at least one montin before the uritten ballots are counted. Several changes in the Constitution will also be up for members' consideration.

5. The NALID Executive Board is considering as the topic of a future newsletter issue, a questionnaire to its members which is designed to find out how schools of comparable size and enrollment compare with one another in regards to equipment, size of instructional tape library, amount of technical and clerical staff in the language laboratory, etc. The tallied results of this questionnaire would be available to any member who responded to the questionaire, and who requested a copy.

If you have prepared any sort of questionnaire which you have sent out to schools or which you have compiled for your own school's administration would you be willing to send three (3) copies of your questionnaire to the editor? He would like to see what questions school directors and administrators want to know. 
NALUD Newsletter.

Volume I, Number 2

Septerber, 1966

Page 3

The NALID Executive Board would be interested in hearing your opinions and ideas on this project: (a) would such information be useful to you, (b) do you like the idea, and (c) do you have any suggestions on what we should ask? etc.

6. Article I, Section-3 (Membership) of the NAItD Constitution restricto membership and voting privileges to bona fide teachers, lab directors, and administrators. Your editor was one of the strongest proponents of this.passage I felt NÁLLD should be a professional educational association run for and by educators; and that there should be no unduerinfluence from people outside the profession, such as publishers, manufacturers of electronic-equipment dealers, etc. Istill feel the same way, but I now believe that we should establish an "associate membership" category whtch would allow such groups to receive our Newsletter. Associate Membership would be asnon-voting memberships The dues would be the same as for any other Newsletter subsription; this wourd work not be a revenue raising venture. It would merely permit groups that we want to with to know what is printed in our Newsletter - which is, after all, the voice of our association. Ule have received numerous requests from such groups of people for subscriptions to our newsletter. I have written many of them aaying that this item will be voted upon at our next of iicial business meeting in April. What do you members feel about this proposal; may we heai from you?

7: Article I, Section 1 (Name) of the NALID Constitution decrees that the official name of the group shall be the National Association of Language Iraboratory Directors. There was considerable discussion at the time of the constitutionls adoption, and also in every one of our regional and business meetings since then. A dissatisfied group kept mentioning that they objected to the word "Language" Laboratory since the growing number of subjects taught with the aid lab equipment extended beyond foreign languages. This is a definite trend; labs are now used to help teach biology, mathematics; typing, dictation, speech, speech correction, medicine, etc. Very frequently t'lese lab installations are put in charge of one director, with one technical.staff, and hence he is often more than the language laboratory director. On the other hand, it is true that the majority of installations with directors teach mainly foreign languages with their equipment - so far at least:

I personally am against changing the association's name in any way that will alter its initials - NALID. We have already become fairly well known as NALLD. and it would seem to me to be folly to change thi.s. I also feel that frankly it is more important what we do than what we are called, because there certainiy are members who need help.

One suggestion might be to consider changing the association!s name to the National Association of Learning Laboratory Directors. May we have members comments about this idea?

8. Article VI, Section I (a) of the NAILD Constitution calls for dues of $\$ 3.00$ per year, with dues running from October to October. The Secretary-Treasurer informs me that we are getting an increasing number of foreign subscriptons where the cost of mailing are considerably higher than local mailing costs. Foreign subscriptions should be mailed first class postage and require special handling to separate from our U.S. Bulk 3rd class mailings. We feel therefore that foreign subscriptions should require higher dues of between $\$ 3.25$ and $\$ 3.50$ per year 
Feature \#1 : IMPORTANT AND PERTINENT ARTICLES APPEARING RECENTLY

A. "On The Usa of Low-Frequency Tones for Marking Language Laboratory Tapes by Robert Krones, Jesse 0. Sawyer, and Glen M. Grosjean. In the journal IANGUAGE IEARNING, Vol. XIV, Nos. 1 and 2 (1964) pp. 51-54.

Also noted in MLabstract, No. 17 of May, 1965 as abstract \# 889 .

This article describes a method of quickly and easily finding a particular

lesson, by using a 40-cycle tone inserted between. lessons. It comparea this method with index counters, white leader tape bands, metalic strips

etc. (This item submitted by the authors, of the University of CalifornzaBerkeley, Califonnia.)

B. The Use and Misuse of Language Laboratories" By, George A. C. Scherer Reprinted from THE GRRIAN QUARTIRLY, Vol. 38, No. 3 (May, 1965) and now available from the MIA.

(This item submitted by Mrs. Jean S. Conkey, of Wheaton College, Norton. Mass.)

Feature \#2: HELPFUL HINTS FOK GOOD LAB MANAGEMNNT

A. Question: When you have a series of fifteen or twenty tapes in one series (perhaps accompanying a specific textbook) - how do you mark the outsida edge of. the box neatly so everyone can read the title?

Answer: One of the neatest ways is, to purchase one or more of the complete alphabet movable band stamps made by Faymus or Pullman and available from most stationery and office supply stores. These come in all sizes, with about sixteen bands wide being the maximum in the AR-1 type style. They work just like a rubber stamp, except that the wording is not fixed. You can also buy these movable band stamps with any combination of alphabet bands mixed with complete number bands. We buy combination alphabet/ number band stamps to print the tape!s catalogue number on the edge of the box. The results are readable, rapid, and neat.

B. Question: If you do not have high quality tape duplication equipment or if your school has no technical staff, where can you get tapes copied so that you may benifit from publishers' tapes on-loan-for-duplication program?

Answer: This may not be the answer in every case - but - the local radia: station has the equipment; Often they have a willingness to accept a tape duplication job for a reasonable fee in order to help the local school. Also investigate the possibility that there exists within your own state a tape duplication service for schools run by the State University Bureau of Audio-Visual Instruction or the county school district. Ask your State Dept. of Public Instruction's foreign language supervisor for NDEA whether such local service exists. Large city school systems are now begining to set up one central processing and duplicating center to duplicate, label, and band tapes for all schools in the system. Perhaps this is a suggestion you should make at the next faculty meeting. 


\section{Feature \# 3: INFORMATION FOR THOSE PLANNING NEW LABS.}

A. IANGUAGE LABORATORY FACILITIES: TECHNICAL GUIDE FOR THE SEUECTION, PURCHASE, USE, AND MAINTENANCE, by Alfred $S$. Hayes for the Electronic Industries Association. Published by the V.S: Dept of HEU, Office of Education as OE - 21024, Bulletin 1963, No. 37-and available irom the superintendent of documents for 50 k. Certainly not ta. be followed exactly; but a very solld point of departure from which you can consider your specific needs.

B. "A GIossary of Tape Recording Terms"n Is a considerably revised and expanded 13 page version of a booklet put out by the $3 M$ Scotch Tape people 3M Booklet \# M-CRG-4-(II5I) MP. Helpful to the beginner threading his way through unfamiliar terminology.

Feature \# 4: LISTING OF POSITIONS AVAILABET. (Administrators and Technicians)

A. Hestern Union has set up a nationwide computer network which.contains in its files individuals' "Career profile". It costs $\$ 1.00$ per month to keep your career profile in the computer file, where prospective employers also have job openings on file which Western Union can match up. There is no placement fee involved. Code numbers, not names are used on the profiles. While this system was set up to help scientests find specialized positions in large corporations, it might be of use to schools or individuals in the academic world. More specific information can be obtained by writing: PICS - Dept. 608

Vestern Union Bldg. 60 Hudson Street

New Yonk, N. Y. 10013

If any of our members have used this service for academic positions, please advise us.

B. Slippery Rock State College/ Slippery Rock, Pennsylvania 160.57

Contact: Professor P. C. Annable, Chairman - Dept. of Modern Languages Requirements: MA in German.

Assignment: Director of Inanguage Laboratory (Half-time) and teaching of German (Half-time).

Salary: According to qualifications and teaching experience.

Academic Rank: Instructor or Assistant Professor according to preparation and experience.

Specifics: New 30 booth Lab to be installed in new building in Sept. 1967.

6. Louisiana State University/ New Orleans; La.

Cóntact: Marie L. LaGarde, Acting Chairman, Dept. of Foreign Languages Requirements: French Preparation. PhD preferred, but MA considered. Assignment: Teaching elementary and intermediate French (half-time) and direct language lab (half-time). Salary: about $\$ 8,500$. for $\mathrm{PhD}$ and from approxinately $\$ 6,500$. to 7,000 . for $\mathrm{MA}$, with adjustments for preparation and laboratory experience. Specifics: Laboratory is run on the Iibrary system; there are no courses scheduled in the lab and director would have nothing to do with student attendance in the lab. 


\section{NeWS BRIEFS}

The trend has been towards putting only one grammatical arili or unt on a tape, because it is so much eisies for teaches's to hanole them or because it is necessiary for use on dial-access protrim library decks One problem in the past was that such short amounts of tape were difficult to handle if you usea seven inch reels, in order to obtain reels large enough to handle all your: Iubels, and boxes Iarge enough to contrin atl your information. Now comes the announcenent from the Plastita neel. Corporation of America (612 Boulevard East, Weehawken New Jersey) that they are mexketing a seven-inch reel with a large forrainch hub moulden from transparent COLORED plastics in red, blue, green, and yellow. Mast impontantly, these reels can now be ordered in reasona le minimum opder quantities 200 per color. In the past, manufaturers were reluctant to sell this particular item in anything less than ton to twenty-five thousand reels per color minimum quantity - which was hardly possible for the majority of schools and colleges! Three cheers for Plastic Reel for changing their minimum quantity on this item so that smail schools could obtain it; I'm sure our color coded tape libraries will benefit from this action. 


\section{Feature \# 5: DIAL-ACCESS INF-RMIATION ROTRIEVAL SYSTEMS.}

A. "Reasons for using two track rather than four track tapesas program sources in Dial-Access Retrieval Systems " is the title of a four page outline prepared by T.R. Goldsworthy. Following the line of reasoning expressed in the article, I have decided to use only one track tapes as program sources for most foreign language materil (hence one tape program per deck). I would be willing to share this mimeograph outline with any NALCD member - as long as my supply lasts - who will send me an addressed envelope, prestamped with five cents postage. Do you have any similar materials you would send on a similar basis?

B. Most automatic program tape decks in a dial-access library have an automatic stop device whtch operates when clear leader tape is gliced to both ends of the tape. Measuring off innumerable 15 to 30 foot pieces of clear leader tape can be made simpler. Simply place two portable recorders 15 feet apart and thread the seveninch reel of clear leader tape on the feed reel of one recorder and the take-up reel of the other recorder. Then turn both machines to ron. Sit at the feed machine and mark a short section of clear leader tape bith black felt marking pen as it leaves the reel. When this black mark reaches the take-up reel of the other recorder, again mark another section of clear leader just as it is leaving the feed reel. The two marks are 15 feet apart. In this way, a whole 1000 foot roll of clear mylar leader tape can be marked into 15 foot sections in a very short time. (This suggestion was suggested by Mr. Phil O'Leary, a student lab assistant formerly at Whitewater State University, Whitewater, Wis. who now works for me in Madison.)

Feature \# 8: LIST OF PRINTED MAT IRIALS AVAILFBLT FROM NALLD.

A. The NALLD Publications Center Mailing Address is:

NALLD Publications Center

\% Language Laboratory

Ohio University

Athens, Ohio 45701

B. Charges: (1) You must be a NALED member to use this service.

(2) You must provide a self-addressed, stamped envelope. (The list will indicate the amount of postage required for each item.)

(3) In many cases, the reprint itself will be free.

C. In the next issue of the newsletter there will be an order blank on which items available will be listed by number, and from which you can order from Ohio Univ.

Do you have materials which you would care to share with other colleagues ?

If so, please send four (4) copies of it along with a brief summary of its uses to the NALLD Executive Board. Indicate whether you could Ioan us the mimeograph stencils from which they are printed. The board will select items of general interest. 